\title{
Mitochondrial regulation of cell death: a phylogenetically conserved control
}

\author{
Lorenzo Galluzzi ${ }^{1,2,3,4,5,{ }^{*} \text {, Oliver Kepp }}{ }^{1,2,3,4,6}$ and Guido Kroemer ${ }^{1,2,3,4,6,6,7,8,{ }^{*}}$ \\ ${ }^{1}$ Equipe 11 labellisée Ligue contre le Cancer, Centre de Recherche des Cordeliers, 75006 Paris, France. \\ ${ }^{2}$ INSERM, U1138, 75006 Paris, France. \\ ${ }^{3}$ Université Paris Descartes/Paris V, Sorbonne Paris Cité, 75006 Paris, France. \\ ${ }^{4}$ Université Pierre et Marie Curie/Paris VI, 75006 Paris. \\ ${ }^{5}$ Gustave Roussy Comprehensive Cancer Institute, 94805 Villejuif, France. \\ ${ }^{6}$ Metabolomics and Cell Biology Platforms, Gustave Roussy Comprehensive Cancer Institute, 94805 Villejuif, France. \\ ${ }^{7}$ Karolinska Institute, Department of Women's and Children's Health, Karolinska University Hospital, 17176 Stockholm, Sweden. \\ ${ }^{8}$ Pôle de Biologie, Hopitâl Européen George Pompidou, AP-HP; 75015 Paris, France. \\ * Corresponding Authors: \\ Lorenzo Galluzzi, E-mail: deadoc@vodafone.it; \\ Guido Kroemer, E-mail: kroemer@orange.fr
}

ABSTRACT Mitochondria are fundamental for eukaryotic cells as they participate in critical catabolic and anabolic pathways. Moreover, mitochondria play a key role in the signal transduction cascades that precipitate many (but not all) regulated variants of cellular demise. In this short review, we discuss the differential implication of mitochondria in the major forms of regulated cell death. doi: $10.15698 /$ mic2016.03.483

Received originally: 08.01.2016;

Accepted 14.01.2016,

Published 23.02.2016.

Keywords: autophagy, apoptosis, autosis, ferroptosis, MTP-driven regulated necrosis, necroptosis, parthanatos, pyroptosis.

\section{Abbreviations:}

MOMP - mitochondrial outer membrane permeabilization, MPT - mitochondrial permeability transition,

$P C D$ - programmed cell death, $R C D$ - regulated cell death.

\section{INTRODUCTION}

Both prokaryotic and eukaryotic cells succumb to very harsh microenvironmental conditions in a virtually instantaneous and uncontrollable manner. Such form of cellular demise, which has been dubbed "accidental cell death" (ACD), reflects the mechanical disassembly of cellular constituents exposed to excessive temperatures, shear forces and/or pressures, and does not involve any molecular machinery [1]. In addition, both prokaryotes and eukaryotes have evolved systems that precipitate the death of cells experiencing moderate but unresolvable perturbations of intracellular or extracellular homeostasis $[2,3]$. This latter form of cellular demise, which has been called "regulated cell death" (RCD), relies on the activation of a geneticallyencoded machinery, and hence can be modulated by means of pharmacological or genetic interventions [1].

Generally, RCD is activated once adaptive response to stress fail at the cellular level, hence constituting a mecha- nism for the preservation of organismal homeostasis [4-7] Defects in the signal transduction cascades that control RCD in eukaryotes have been associated with clinically relevant conditions including acute brain injury, neurodegeneration, cardiac stroke, hepatic damage, and viral infection (all of which are associated with the excessive demise of post-mitotic cells), as well as autoimmune disorders and neoplastic conditions (which are linked to defective RCD) [8-10].

Of note, one specific variant of RCD that is known as "programmed cell death" (PCD) is initiated at a predetermined point of a cell's life, as a part of (post-)embryonic development or the maintenance of tissue homeostasis in the adult $[1,11]$. PCD relies on the same molecular machinery underlying stress-initiated forms of RCD, implying that it can also be retarded or accelerated with specific chemicals or genetic maneuvers $[1,11]$. 
The signal transduction cascades controlling RCD have expanded considerably throughout evolution, especially (1) once eukaryotic life has been established (i.e., when organelles including mitochondria became available), and (2) along with the transition from a purely unicellular state to multicellularity (through colonial life) [12-14]. Nowadays at least five mechanistically distinct variants of RCD have been described in mammals $[1,15]$ : (1) intrinsic apoptosis [16-18], (2) extrinsic apoptosis [18, 19], (3) necroptosis [2022], (4) mitochondrial permeability transition (MPT)-driven regulated necrosis [22-24], and (5) ferroptosis [25, 26]. Moreover, other forms or RCD including parthanatos, autosis and pyroptosis are being characterized with increased precision [27-31]. In this short review, we discuss the differential role of mitochondria (which are quintessential for eukaryotic life as they mediate critical bioenergetic and anabolic functions) [32] in the main forms of RCD.

\section{MITOCHONDRIA AND INTRINSIC APOPTOSIS}

Intrinsic apoptosis is a form of RCD initiated by perturbations of intracellular homeostasis that relies on the catalytic activity of the cysteine protease caspase-3 (CASP3) [1, 15-18]. In this context, the proteolytic activation of CASP3 is catalyzed by caspase-9 (CASP9), which in turn acquires catalytic activity within a supramolecular complex that is known as "apoptosome" and also contains deoxyATP, the cytosolic adaptor apoptotic peptidase activating factor 1 (APAF1) and an extramitochondrial pool of cytochrome $c$, somatic (CYCS, best known as CYTC) [33, 34].

In physiological conditions, CYTC exclusively resides between the outer and the inner mitochondrial membrane, where it is loosely associated with the latter as it operates as an electron shuttle of the respiratory chain [35]. Various perturbations of intracellular homeostasis, however, cause the oligomerization of two members of the $\mathrm{Bcl}-2$ protein family, namely BCL2-associated X protein (BAX)- and BCL2antagonist/killer 1 (BAK1), in the outer mitochondrial membrane, hence altering its permeability to proteins [36]. Oligomerized BAX and BAK1 also cause rearrangements of the mitochondrial ultrastructure that facilitate the release of CYTC into the cytosol and hence the activation of the apoptosome [33]. Thus, mitochondrial outer membrane permeabilization (MOMP) is a crucial step in the signal transduction cascades that fuel intrinsic apoptosis [36].

In line with this notion, several proteins with prominent anti-apoptotic functions, including various other members of the Bcl-2 family like B-cell CLL/lymphoma 2 (BCL2) itself, BCL2-like 1 (BCL2L1, best known as BCL- $\mathrm{K}_{\mathrm{L}}$ ) and myeloid cell leukemia 1 (MCL1), mainly operate by preventing MOMP [37].

There are at least two distinct mechanisms whereby BCL2-like proteins mediate such an effect: (1) by physically interacting with BAX and BAK1 and hence preventing their oligomerization [37]; and (2) by sequestering other members of the Bcl-2 protein family that activate BAX and BAK1 in response to stress, the so-called "BH3-only proteins" [38]. Moreover, $B C L-X_{L}$ has been attributed the capacity to retrotranslocate active BAX to the cytosol (where it normally resides in its inactive state) [39].

Importantly, MOMP drives intrinsic apoptosis not only as it initiates the apoptosome-dependent activation of CASP3 (which cleaves several substrates that are important for cellular survival), but also because it entails the immediate dissipation of the mitochondrial transmembrane potential $\left(\Delta \psi_{\mathrm{m}}\right.$, which is required for ATP synthesis and several other mitochondrial functions) $[40,41]$. This implies that intrinsic apoptosis can occur even in the absence of APAF1, CASP9 and CASP3 (or in the presence of chemical agents specifically targeting these proteins) [1]. However, the inhibition of APAF1, CASP9 or CASP3 generally delays intrinsic apoptosis and alters several of its manifestations [1]. Indeed, CASP3 is mechanistically responsible for various biochemical, morphological and immunological features of apoptosis, including the exposure of phosphatidylserine (PS) on the surface of dying cells [42, 43], DNA fragmentation (which underlies nuclear condensation) [44, 45], and the release of the immunosuppressive factor prostaglandin $E_{2}\left(P E_{2}\right)$ [46]. In spite of the precise kinetics of the process, mitochondria play a key role in the signal transduction cascades that precipitate intrinsic apoptosis.

\section{MITOCHONDRIA AND EXTRINSIC APOPTOSIS}

Extrinsic apoptosis is a CASP3-dependent form of RCD initiated by perturbations of the extracellular microenvironment $[1,15,19,47]$. Extrinsic apoptosis can be elicited by two classes of plasma membrane receptors that operate in a diametrically opposed fashion: (1) so-called "dependence receptors", which acquire pro-apoptotic activity when the concentration of their ligands falls below a specific threshold [47]; and (2) so-called "death receptors", which trigger RCD in the presence of their ligands [19]. The molecular mechanisms bridging dependence receptors to the transmission of an RCD-promoting signal have not been elucidated yet, and appear to exhibit a remarkable degree of context-dependency [47]. Thus, while unbound patched 1 (PTCH1) and deleted in colorectal carcinoma (DCC) appear to interact with the cytosolic adaptor four and a half LIM domains 2 (FHL2, best known as DRAL) to assemble a supramolecular complex that promotes the activation of CASP9 $[48,49]$, other dependence receptors like unc-5 netrin receptor $B$ (UNC5B) have been shown to respond to ligand withdrawal by triggering a death-associated protein kinase 1 (DAPK1)-dependent signaling pathway [50].

The signal transduction cascades activated by death receptors upon ligand binding, conversely, are well characterized. Normally, FAS trimers (which assemble and disassemble spontaneously) get stabilized in the presence of FAS ligand (FASLG), favoring the recruitment of a large multiprotein complex at the cytosolic tail of the receptor [19]. This supramolecular entity, which is known as "deathinducing signaling complex" (DISC), contains receptorinteracting protein kinase 1 (RIPK1), FAS-associated protein with a death domain (FADD), various isoforms of CASP8 and FADD like apoptosis regulator (CFLAR, best known as CFLIP) as well as several members of the baculoviral IAP 
repeat containing (BIRC) protein family (which act as E3 ubiquitin ligases), and operates as an activating platform for caspase-8 (CASP8) or caspase-10 (CASP10). CASP8 (as well as CASP10) can catalyze the proteolytic activation of CASP3, hence precipitating apoptotic RCD [51, 52], while the other components of the DISC either (1) play structural roles (like FADD does), (2) mediate direct RCD-inhibitory functions (like BIRC proteins and C-FLIP do), or (3) connect DISC activation to other signal transduction cascades including the activation of the pro-inflammatory transcription factor NF-kB (like RIPK1 does) [53].

Importantly, distinct death receptors assemble structurally different DISCs upon activation, implying that the signaling pathway initiated by death receptors can exhibit a remarkable degree of variation (although they generally culminate in CASP8 or CASP10 activation) [53]. In some cell types (which are commonly referred to as Type I cells, e.g., lymphocytes), the activation of CASP8 by the DISC is perfectly sufficient to drive CASP3-dependent apoptotic RCD [54]. However, in other cell types (which are commonly indicated as Type II cells, e.g., hepatocytes), the optimal activation of CASP3 by CASP8 critically relies on MOMP [54]. In this setting, MOMP is driven by the CASP8catalyzed activation of $\mathrm{BH} 3$ interacting domain death agonist (BID), a potent $\mathrm{BH} 3$ only protein $[55,56]$. Whether cells behave in a Type I or Type II manner upon death receptor ligation depends on the cytosolic abundance of X-linked inhibitor of apoptosis (XIAP), a BIRC family members that exerts potent caspase-inhibitory functions [57]. Thus, mitochondria play an active role in some (but not all) instances of extrinsic apoptosis.

\section{MITOCHONDRIA AND NECROPTOSIS}

Necroptosis is a variant of RCD that obligatorily relies on the activation of the RIPK1-like protein receptor-interacting protein kinase 3 (RIPK3) and the pseudokinase mixed lineage kinase domain-like (MLKL), and generally manifests with a necrotic morphology [1, 15, 20-22]. Various (but not all) instances of necroptosis also impinge on the activation of RIPK1 itself, implying that they can be retarded by the RIPK1-targeting agent necrostatin-1 (Nec-1). For instance, this applies to necroptosis elicited by tumor necrosis factor receptor superfamily member $1 \mathrm{~A}$ (TNFRSF1A) ligation in CASP8-deficient conditions [58-60]. Heterotrimeric complexes containing CASP8, FADD and the long isoform of cFLIP operate indeed as tonic inhibitors of necroptosis, normally preventing the activation of this RCD modality upon death receptor ligation [61, 62]. However, when RIPK1 ubiquitination by BIRC family members is chemically antagonized (with agents commonly known as Smac mimetics) and CASP8 is absent or blocked, prolonged TNFRSF1A signaling efficiently drive the assembly of a RIPK1- and RIPK3-containing complex that phosphorylates $M L K L$, endowing it with the ability to translocate to the inner leaflet of the plasma membrane and compromise its structural integrity [63-66].

Initially, mitochondria were thought to participate in necroptotic signaling in at least two ways: (1) necroptosis was linked to an oxidative burst caused by the RIPK3dependent activation of various metabolic enzymes, including mitochondrial glutamate dehydrogenase 1 (GLUD1) [67], and (2) MLKL was suggested to boost the catalytic activity of PGAM family member 5 , serine/threonine protein phosphatase, mitochondrial (PGAM5), resulting in the activating dephosphorylation of dynamin 1-like (DNM1L, best known as DRP1) and consequent mitochondria fragmentation [68, 69]. Subsequent evidence from several independent laboratories, however, demonstrated that mitochondria are completely dispensable for necroptosis. Indeed, necroptotic signaling was found to be normal in cells lacking mitochondria upon a widespread mitophagic response [70], as well as in cells from Pgam $5^{\%}$ mice [71]. Very recent findings linking MLKL to mitochondrial MCL1 depletion and consequent MOMP remain to be verified [72]. Thus, necroptosis should be considered as a mitochondrion-independent form of RCD.

\section{MITOCHONDRIA AND MPT-DRIVEN REGULATED NE- CROSIS}

The term MPT is commonly employed to indicate an abrupt increase in the permeability of the inner mitochondrial membrane to small solutes, resulting in immediate $\Delta \psi_{\mathrm{m}}$ dissipation, massive water intake, and osmotic organelle breakdown [1, 15, 22-24]. According to current models, the MPT ensues a conformational change in a multiprotein complex assembled at the juxtaposition between the inner and outer mitochondrial membranes, the so-called "permeability transition pore complex", (PTPC) [17, 24]. The precise molecular composition of the PTPC remains matter of debate and may exhibit considerable degree of context dependency $[17,24]$. However, at least one protein has been attributed a key, non-redundant role in MPT, i.e., peptidylprolyl isomerase F (PPIF, best known as CYPD) [7375]. Recent findings suggest that also the $c$ subunit of the $F_{0}$ ATPase (which in humans exists in 3 isoforms, ATP5G13) plays a critical function within the PTPC [76], yet compelling genetic evidence in support of this hypothesis is difficult to obtain. Irrespective of this unknown, MPT results in a rapid drop of intracellular ATP availability, driving a form of RCD that generally manifests with necrotic morphological features $[17,44]$. As per definition, MTP-driven regulated necrosis occurs with a delayed kinetics in cells lacking CYPD, as well as in the presence of the chemical CYPD inhibitor cyclosporin A (CsA) $[1,15]$. Thus, mitochondria play a fundamental role in the signal transduction cascades underlying MPT-driven regulated necrosis.

\section{MITOCHONDRIA AND FERROPTOSIS}

Ferroptosis is an iron-dependent form RCD generally initiated by the inhibition of plasma membrane system $\mathrm{x}_{\mathrm{C}^{-}}$(a cystine/glutamate antiporter), resulting in the depletion of antioxidant defenses and lethal lipid peroxidation $[1,15,25$, 26]. Ferroptosis is under the endogenous control of cytosolic glutathione peroxidase 4 (GPX4) $[77,78]$, and can be delayed by the small molecule ferrostatin-1 (Fer-1) as well 
as by other chemical agents that inhibit lipid peroxidation [79].

Of note, Fer-1 and alike fail to inhibit the generation of mitochondrial reactive oxygen species (ROS) [79]. Moreover, ferroptosis proceeds normally in Ppif ${ }^{\prime-}$ cells as well as in the presence of the MPT inhibitor CsA [80]. Thus, it seems that mitochondria and mitochondrial ROS are perfectly dispensable for ferroptosis, although this conjecture has not yet been addressed experimentally in a direct fashion.

\section{MITOCHONDRIA AND OTHER FORMS OF RCD Parthanatos}

Parthanatos is a peculiar form or RCD depending on poly(ADP-ribose) polymerase 1 (PARP1), a nuclear protein involved in DNA repair, and apoptosis inducing factor, mitochondria associated 1 (AIFM1) [1, 15, 81]. PARP1 hyperactivation by DNA alkylating agents entails a very pronounced depletion in intracellular $\mathrm{NAD}^{+}$stores, resulting in a potentially lethal bioenergetic crisis [82]. Moreover, poly(ADP-ribose) moieties generated by PARP1 appear to bind AIFM1 in the mitochondrial intermembrane space, hence favoring its release to the cytosol [83]. Upon binding to peptidylprolyl isomerase A (PPIFA, best known as CYPA), extramitochondrial AIFM1 acquires the ability to translocate to the nucleus and mediate large-scale DNA fragmentation [83]. Mitochondria are therefore required for parthanatos to proceed according to a normal kinetics.

Autosis
Autosis is a variant of autophagic cell death, i.e., a form of RCD that is precipitated by the molecular machinery for macroautophagy $[1,15,27,28]$. In addition, autosis impinges on the plasma membrane $\mathrm{Na}^{+} / \mathrm{K}^{+}$ATPase, implying that it can be modulated with chemical agents that target this ionic pump, like cardiac glycosides [27, 84]. The morphological manifestations of autosis differ from those of classical apoptosis and necrosis, encompassing a pathognomonic dilation of the perinuclear space and the massive accumulation of autophagic vacuoles in the cytoplasm [27, $28,44]$. Although some components of the molecular machinery for macroautophagy interact with mitochondrial proteins (including BCL2), the involvement of mitochondria in the signal transduction cascades that precipitate autosis has not been investigated yet.

\section{Pyroptosis}

Pyroptosis is a form of RCD that critically rely on the cleavage of gasdermin D (GSDMD) by inflammatory caspases, i.e., caspase-1 (CASP1), caspase-4 (CASP4), caspase-5 (CASP5) or caspase-11 (Casp11, the mouse orthologue of human CASP4 and CASP5) [1, 15, 29-31]. Thus, pyroptosis is generally associated with the assembly and activation of so-called "inflammasomes", which are supramolecular platforms that promote the CASP1-, CASP4-, CASP5- or Casp11-dependent proteolytic processing of prointerleukin-1 $\beta$ (pro-IL-1 $\beta$ ) and pro-interleukin-18 (pro-IL18) [85]. These observations imply that pyroptosis (1) can only occur in cell types that express sufficient amount of inflammatory caspases (e.g., cells of the monocytic lineage)

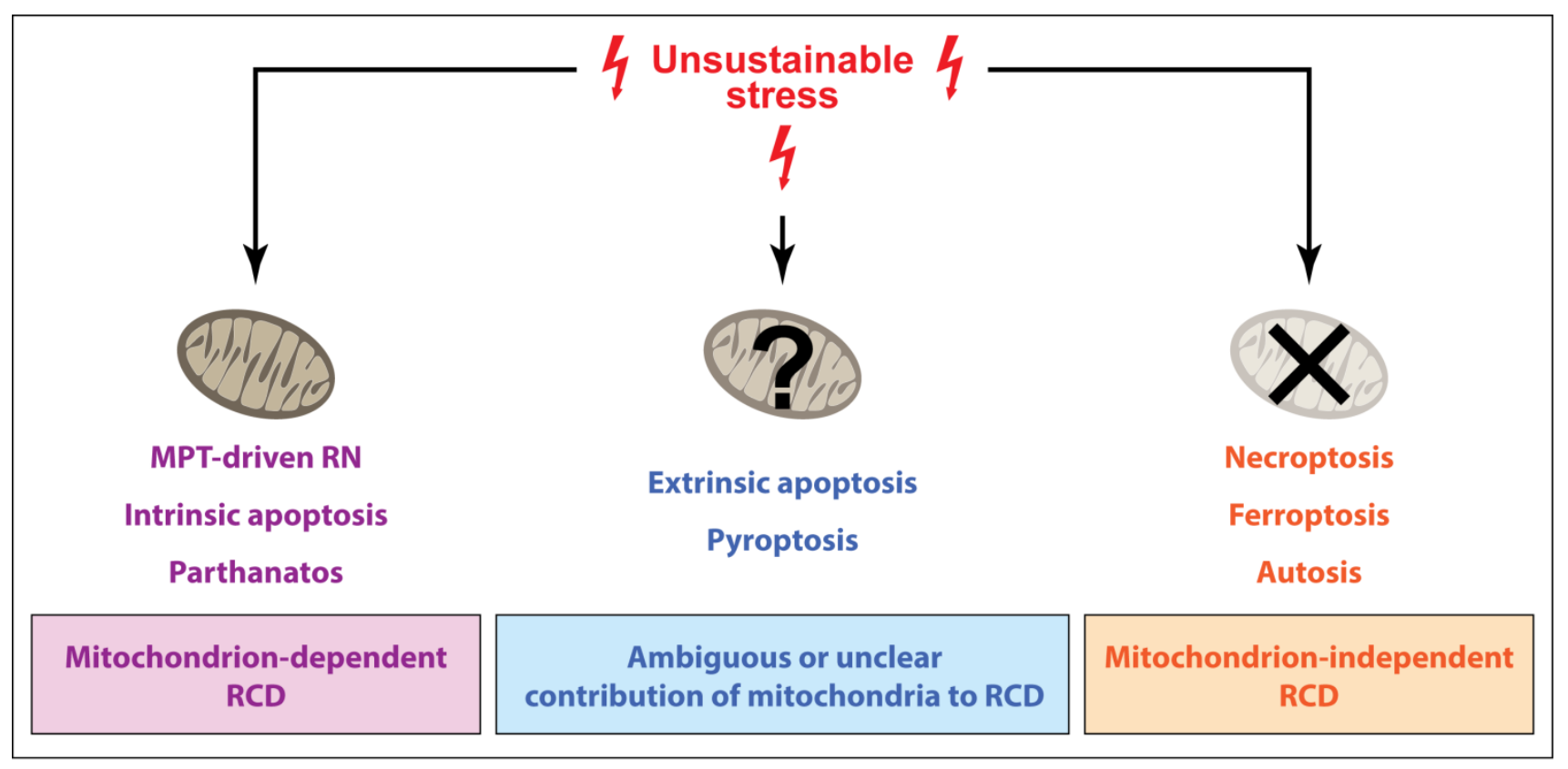

FIGURE 1: Implication of mitochondria in RCD signaling. Mitochondria play a key, non-redundant role in the signal transduction cascades that precipitate intrinsic apoptosis, some instances of extrinsic apoptosis, mitochondrial permeability transition (MPT)-driven regulated necrosis (RN), and parthanatos, but are completely dispensable for necroptosis, ferroptosis, and autophagic cell death by autosis (at least according to current knowledge). The actual contribution of mitochondria to the signaling pathways that drive pyroptotic regulated cell death (RCD) remains to be formally elucidated. 
[86], (2) is associated with the release of mature IL-1 $\beta$ and IL-18 [86], and (3) is sensitive to broad-spectrum caspase inhibitors like Z-VAD-fmk (which also delays apoptosis) as well as to chemicals that specifically block CASP1, CASP4, CASP5 or Casp11 (which have no effects on apoptosis) [1].

Morphologically, pyroptosis manifests with features that resemble (at least in part) those of apoptosis [44, 87]. Importantly, mitochondrial ROS have been shown to act as intracellular danger signals and promote inflammasome activation coupled CASP1-dependent RCD in some cells [88]. However, the integrity of mitochondria appears to be preserved in the first phases of pyroptotic signaling [89-91]

In summary, it remains to be formally demonstrated whether mitochondria are a core component of the signal transduction cascades that precipitate pyroptosis or whether they simply act as pyroptosis initiators in specific pathophysiological settings.

\section{CONCLUDING REMARKS}

The signal transduction cascades that precipitate RCD have become increasingly more complex with evolution, especially along with the acquisition of the eukaryotic state and multicellularity [12-14, 92]. Modern prokaryotes harness RCD to favor the survival of the species when colonies are threatened by environmental conditions [93, 94], and it seems that such an evolutionarily ancient capacity has been fixed by evolution. Mitochondria (the remnants of bacteria that at some stage were incorporated into protoeukaryotes to generate eukaryotic life) play indeed a fundamental function in some (but not all) RCD-stimulating pathways in modern eukaryotes (Figure 1). Interestingly

\section{REFERENCES}

1. Galluzzi L, Bravo-San Pedro JM, Vitale I, Aaronson SA, Abrams JM, Adam D, Alnemri ES, Altucci L, Andrews D, Annicchiarico-Petruzzelli M, Baehrecke EH, Bazan NG, Bertrand MJ, Bianchi K, Blagosklonny MV, Blomgren K, Borner C, Bredesen DE, Brenner C, Campanella M, Candi E, Cecconi F, Chan FK, Chandel NS, Cheng EH, Chipuk JE, Cidlowski JA, Ciechanover A, Dawson TM, Dawson VL, et al. (2015). Essential versus accessory aspects of cell death: recommendations of the NCCD 2015. Cell Death Differ 22(1): 58-73.

2. Galluzzi L, Bravo-San Pedro JM, Kroemer G (2014). Organellespecific initiation of cell death. Nat Cell Biol 16(8): 728-736.

3. Green DR, Galluzzi L, Kroemer G (2014). Cell biology. Metabolic control of cell death. Science 345(6203): 1250256.

4. Green DR, Levine B (2014). To be or not to be? How selective autophagy and cell death govern cell fate. Cell 157(1): 65-75.

5. Hetz C, Chevet E, Harding HP (2013). Targeting the unfolded protein response in disease. Nat Rev Drug Discov 12(9): 703-719.

6. Sica V, Galluzzi L, Bravo-San Pedro JM, Izzo V, Maiuri MC, Kroemer G (2015). Organelle-specific initiation of autophagy. Mol Cell 59(4): 522-539.

7. Galluzzi L, Pietrocola F, Bravo-San Pedro JM, Amaravadi RK, Baehrecke EH, Cecconi F, Codogno $P$, Debnath J, Gewirtz DA, Karantza V, Kimmelman A, Kumar S, Levine B, Maiuri MC, Martin SJ, Penninger J, Piacentini M, Rubinsztein DC, Simon HU, Simonsen A, Thorburn AM, Velasco G, Ryan KM, Kroemer G (2015). Autophagy in malignant transformation and cancer progression. EMBO J 34(7): 856-880. enough, evolutionarily ancient eukaryotes including Saccharomyces cerevisiae mostly (if not exclusively) rely on mitochondrion-dependent forms of RCD [92, 95-97]. Conversely, mitochondrion-dependent RCD variants seem to have completely disappeared in post-mitotic animals like Caenorhabditis elegans [98] and Drosophila melanogaster [99]. Taken together, these observations suggest that $\mathrm{mi}$ tochondrion-dependent variants of RCD may have evolved before their mitochondrion-independent counterparts.

In conclusion, mitochondria are quintessential for eukaryotic cells, not only as they mediate fundamental bioenergetic and anabolic functions, but also as they contribute to several (but not all) signal transduction cascades that precipitate RCD.

\section{CONFLICT OF INTEREST}

The authors have no conflicts of interest to disclose.

\section{COPYRIGHT}

(C) 2016 Galluzzi et al. This is an open-access article released under the terms of the Creative Commons Attribution (CC BY) license, which allows the unrestricted use, distribution, and reproduction in any medium, provided the original author and source are acknowledged.

Please cite this article as: Lorenzo Galluzzi, Oliver Kepp and Guido Kroemer (2016). Mitochondrial regulation of cell death: a phylogenetically conserved control. Microbial Cell 3(3): 101-108. doi: 10.15698/mic2016.03.483

8. Galluzzi L, Blomgren K, Kroemer G (2009). Mitochondrial membrane permeabilization in neuronal injury. Nat Rev Neurosci 10(7): 481-494.

9. Friese MA, Schattling B, Fugger L (2014). Mechanisms of neurodegeneration and axonal dysfunction in multiple sclerosis. Nat Rev Neurol 10(4): 225-238.

10. Brenner C, Galluzzi L, Kepp O, Kroemer G (2013). Decoding cell death signals in liver inflammation. J Hepatol 59(3): 583-594.

11. Fuchs $Y$, Steller $H$ (2011). Programmed cell death in animal development and disease. Cell 147(4): 742-758.

12. Green DR, Victor B (2012). The pantheon of the fallen: why are there so many forms of cell death? Trends Cell Biol 22(11): 555-556.

13. Bender CE, Fitzgerald P, Tait SW, Llambi F, McStay GP, Tupper DO, Pellettieri J, Sanchez Alvarado A, Salvesen GS, Green DR (2012). Mitochondrial pathway of apoptosis is ancestral in metazoans. Proc Natl Acad Sci U S A 109(13): 4904-4909.

14. Degterev A, Yuan J (2008). Expansion and evolution of cell death programmes. Nat Rev Mol Cell Biol 9(5): 378-390.

15. Galluzzi L, Vitale I, Abrams JM, Alnemri ES, Baehrecke EH, Blagosk lonny MV, Dawson TM, Dawson VL, El-Deiry WS, Fulda S, Gottlieb E, Green DR, Hengartner MO, Kepp O, Knight RA, Kumar S, Lipton SA, Lu $X$, Madeo F, Malorni W, Mehlen P, Nunez G, Peter ME, Piacentini M, Rubinsztein DC, Shi Y, Simon HU, Vandenabeele P, White E, Yuan J, et al. (2012). Molecular definitions of cell death subroutines: recommendations of the Nomenclature Committee on Cell Death 2012. Cell Death Differ 19(1): 107-120. 
16. Tait SW, Green DR (2010). Mitochondria and cell death: outer membrane permeabilization and beyond. Nat Rev Mol Cell Biol 11(9): 621-632.

17. Kroemer G, Galluzzi L, Brenner C (2007). Mitochondrial membrane permeabilization in cell death. Physiol Rev 87(1): 99-163.

18. Taylor RC, Cullen SP, Martin SJ (2008). Apoptosis: controlled demolition at the cellular level. Nat Rev Mol Cell Biol 9(3): 231-241.

19. Wajant $H$ (2002). The Fas signaling pathway: more than a paradigm. Science 296(5573): 1635-1636.

20. Vandenabeele P, Galluzzi L, Vanden Berghe T, Kroemer G (2010). Molecular mechanisms of necroptosis: an ordered cellular explosion. Nat Rev Mol Cell Biol 11(10): 700-714.

21. Linkermann A, Green DR (2014). Necroptosis. N Engl J Med 370(5): 455-465.

22. Vanden Berghe $T$, Linkermann A, Jouan-Lanhouet $S$, Walczak $H$, Vandenabeele $P$ (2014). Regulated necrosis: the expanding network of non-apoptotic cell death pathways. Nat Rev Mol Cell Biol 15(2): 135147

23. Galluzzi L, Kepp O, Krautwald S, Kroemer G, Linkermann A (2014). Molecular mechanisms of regulated necrosis. Semin Cell Dev Biol 35:24-32.

24. Bonora M, Wieckowski MR, Chinopoulos C, Kepp O, Kroemer G Galluzzi L, Pinton P (2015). Molecular mechanisms of cell death: central implication of ATP synthase in mitochondrial permeability transition. Oncogene 34(12): 1475-1486.

25. Linkermann A, Skouta R, Himmerkus N, Mulay SR, Dewitz C, De Zen F, Prokai A, Zuchtriegel G, Krombach F, Welz PS, Weinlich R, Vanden Berghe $T$, Vandenabeele $P$, Pasparakis $M$, Bleich $M$, Weinberg JM, Reichel CA, Brasen JH, Kunzendorf U, Anders HJ, Stockwell BR, Green $D R$, Krautwald S (2014). Synchronized renal tubular cell death involves ferroptosis. Proc Natl Acad Sci U S A 111(47): 16836-16841.

26. Dixon SJ, Lemberg KM, Lamprecht MR, Skouta R, Zaitsev EM, Gleason CE, Patel DN, Bauer AJ, Cantley AM, Yang WS, Morrison B, 3rd, Stockwell BR (2012). Ferroptosis: an iron-dependent form of nonapoptotic cell death. Cell 149(5): 1060-1072.

27. Liu Y, Shoji-Kawata S, Sumpter RM, Jr., Wei Y, Ginet V, Zhang L, Posner B, Tran KA, Green DR, Xavier RJ, Shaw SY, Clarke PG, Puyal J, Levine B (2013). Autosis is a $\mathrm{Na}+, \mathrm{K}+-\mathrm{ATP}$ ase-regulated form of cell death triggered by autophagy-inducing peptides, starvation, and hypoxia-ischemia. Proc Natl Acad Sci U S A 110(51): 20364-20371.

28. Liu Y, Levine B (2015). Autosis and autophagic cell death: the dark side of autophagy. Cell Death Differ 22(3): 367-376.

29. Kayagaki N, Stowe IB, Lee BL, O'Rourke K, Anderson K, Warming S, Cuellar T, Haley B, Roose-Girma M, Phung QT, Liu PS, Lill JR, Li H, Wu J, Kummerfeld S, Zhang J, Lee WP, Snipas SJ, Salvesen GS, Morris LX, Fitzgerald L, Zhang Y, Bertram EM, Goodnow CC, Dixit VM (2015). Caspase-11 cleaves gasdermin $D$ for non-canonical inflammasome signaling. Nature.

30. Shi J, Zhao Y, Wang K, Shi X, Wang Y, Huang H, Zhuang Y, Cai T, Wang $F$, Shao $F$ (2015). Cleavage of GSDMD by inflammatory caspases determines pyroptotic cell death. Nature.

31. Lim Y, Kumar S (2015). A single cut to pyroptosis. Oncotarget 6(35): 36926-36927.

32. Galluzzi L, Kepp O, Kroemer G (2012). Mitochondria: master regulators of danger signalling. Nat Rev Mol Cell Biol 13(12): 780-788.

33. Liu X, Kim CN, Yang J, Jemmerson R, Wang X (1996). Induction of apoptotic program in cell-free extracts: requirement for dATP and cytochrome c. Cell 86(1): 147-157.
34. Zou H, Henzel WJ, Liu X, Lutschg A, Wang X (1997). Apaf-1, a human protein homologous to $C$. elegans CED-4, participates in cytochrome c-dependent activation of caspase-3. Cell 90(3): 405-413.

35. Galluzzi L, Kepp O, Trojel-Hansen C, Kroemer G (2012). Nonapoptotic functions of apoptosis-regulatory proteins. EMBO Rep 13(4): 322-330.

36. Wei MC, Zong WX, Cheng EH, Lindsten T, Panoutsakopoulou $\mathrm{V}$ Ross AJ, Roth KA, MacGregor GR, Thompson CB, Korsmeyer SJ (2001). Proapoptotic BAX and BAK: a requisite gateway to mitochondrial dysfunction and death. Science 292(5517): 727-730

37. Czabotar PE, Lessene G, Strasser A, Adams JM (2014). Control of apoptosis by the BCL-2 protein family: implications for physiology and therapy. Nat Rev Mol Cell Biol 15(1): 49-63.

38. Chipuk JE, Green DR (2008). How do BCL-2 proteins induce mitochondrial outer membrane permeabilization? Trends Cell Biol 18(4): 157-164.

39. Edlich F, Banerjee S, Suzuki M, Cleland MM, Arnoult D, Wang C, Neutzner A, Tjandra N, Youle RJ (2011). Bcl-x(L) retrotranslocates Bax from the mitochondria into the cytosol. Cell 145(1): 104-116.

40. Zamzami N, Marchetti P, Castedo M, Decaudin D, Macho A, Hirsch T, Susin SA, Petit PX, Mignotte B, Kroemer G (1995). Sequential reduction of mitochondrial transmembrane potential and generation of reactive oxygen species in early programmed cell death. J Exp Med 182(2): 367-377.

41. Zamzami N, Marchetti P, Castedo M, Zanin C, Vayssiere JL, Petit $\mathrm{PX}$, Kroemer $\mathrm{G}$ (1995). Reduction in mitochondrial potential constitutes an early irreversible step of programmed lymphocyte death in vivo. J Exp Med 181(5): 1661-1672.

42. Segawa K, Kurata S, Yanagihashi Y, Brummelkamp TR, Matsuda F, Nagata S (2014). Caspase-mediated cleavage of phospholipid flippase for apoptotic phosphatidylserine exposure. Science 344(6188): 1164 1168

43. Suzuki J, Denning DP, Imanishi E, Horvitz HR, Nagata S (2013). Xkrelated protein 8 and CED-8 promote phosphatidylserine exposure in apoptotic cells. Science 341(6144): 403-406.

44. Kroemer G, Galluzzi L, Vandenabeele P, Abrams J, Alnemri ES, Baehrecke EH, Blagosklonny MV, El-Deiry WS, Golstein P, Green DR, Hengartner M, Knight RA, Kumar S, Lipton SA, Malorni W, Nunez G, Peter ME, Tschopp J, Yuan J, Piacentini M, Zhivotovsky B, Melino G Nomenclature Committee on Cell D (2009). Classification of cell death: recommendations of the Nomenclature Committee on Cell Death 2009. Cell Death Differ 16(1): 3-11.

45. Enari M, Sakahira H, Yokoyama H, Okawa K, Iwamatsu A, Nagata S (1998). A caspase-activated DNase that degrades DNA during apoptosis, and its inhibitor ICAD. Nature 391(6662): 43-50.

46. Huang Q, Li F, Liu X, Li W, Shi W, Liu FF, O'Sullivan B, He Z, Peng Y, Tan AC, Zhou L, Shen J, Han G, Wang XJ, Thorburn J, Thorburn A, Jimeno A, Raben D, Bedford JS, Li CY (2011). Caspase 3-mediated stimulation of tumor cell repopulation during cancer radiotherapy. Nat Med 17(7): 860-866.

47. Gibert B, Mehlen P (2015). Dependence Receptors and Cancer: Addiction to Trophic Ligands. Cancer Res 75(24): 5171-5175.

48. Fombonne J, Bissey PA, Guix C, Sadoul R, Thibert C, Mehlen P (2012). Patched dependence receptor triggers apoptosis through ubiquitination of caspase-9. Proc Natl Acad Sci U S A 109(26): 1051010515.

49. Mille F, Thibert C, Fombonne J, Rama N, Guix C, Hayashi H, Corset V, Reed JC, Mehlen P (2009). The Patched dependence receptor triggers apoptosis through a DRAL-caspase-9 complex. Nat Cell Biol 11(6): 739-746. 
50. Guenebeaud C, Goldschneider D, Castets M, Guix C, Chazot G, Delloye-Bourgeois C, Eisenberg-Lerner A, Shohat G, Zhang M, Laudet $V$, Kimchi A, Bernet A, Mehlen $P$ (2010). The dependence receptor UNC5H2/B triggers apoptosis via PP2A-mediated dephosphorylation of DAP kinase. Mol Cell 40(6): 863-876.

51. Muzio M, Chinnaiyan AM, Kischkel FC, O'Rourke K, Shevchenko A, Ni J, Scaffidi C, Bretz JD, Zhang M, Gentz R, Mann M, Krammer PH, Peter ME, Dixit VM (1996). FLICE, a novel FADD-homologous ICE/CED3-like protease, is recruited to the CD95 (Fas/APO-1) death--inducing signaling complex. Cell 85(6): 817-827.

52. Medema JP, Scaffidi C, Kischkel FC, Shevchenko A, Mann M, Krammer PH, Peter ME (1997). FLICE is activated by association with the CD95 death-inducing signaling complex (DISC). EMBO J 16(10): 2794-2804.

53. Schutze S, Tchikov V, Schneider-Brachert W (2008). Regulation of TNFR1 and CD95 signalling by receptor compartmentalization. Nat Rev Mol Cell Biol 9(8): 655-662.

54. Barnhart BC, Alappat EC, Peter ME (2003). The CD95 type I/type II model. Semin Immunol 15(3): 185-193.

55. Li H, Zhu H, Xu CJ, Yuan J (1998). Cleavage of BID by caspase 8 mediates the mitochondrial damage in the Fas pathway of apoptosis. Cell 94(4): 491-501.

56. Yin XM, Wang K, Gross A, Zhao Y, Zinkel S, Klocke B, Roth KA, Korsmeyer SJ (1999). Bid-deficient mice are resistant to Fas-induced hepatocellular apoptosis. Nature 400(6747): 886-891.

57. Jost PJ, Grabow S, Gray D, McKenzie MD, Nachbur U, Huang DC, Bouillet P, Thomas HE, Borner C, Silke J, Strasser A, Kaufmann T (2009). XIAP discriminates between type I and type II FAS-induced apoptosis. Nature 460(7258): 1035-1039.

58. Hitomi J, Christofferson DE, Ng A, Yao J, Degterev A, Xavier RJ, Yuan J (2008). Identification of a molecular signaling network that regulates a cellular necrotic cell death pathway. Cell 135(7): 13111323.

59. Degterev A, Hitomi J, Germscheid M, Ch'en IL, Korkina O, Teng X, Abbott D, Cuny GD, Yuan C, Wagner G, Hedrick SM, Gerber SA, Lugovskoy A, Yuan J (2008). Identification of RIP1 kinase as a specific cellular target of necrostatins. Nat Chem Biol 4(5): 313-321.

60. Degterev A, Huang Z, Boyce M, Li Y, Jagtap P, Mizushima N, Cuny GD, Mitchison TJ, Moskowitz MA, Yuan J (2005). Chemical inhibitor of nonapoptotic cell death with therapeutic potential for ischemic brain injury. Nat Chem Biol 1(2): 112-119.

61. Dillon $C P$, Oberst A, Weinlich $R$, Janke $L$, Kang TB, Ben-Moshe T, Mak TW, Wallach D, Green DR (2012). Survival function of the FADDCASPASE-8-cFLIP(L) complex. Cell Rep 1(5): 401-407.

62. Weinlich R, Oberst A, Dillon CP, Janke LJ, Milasta S, Lukens JR, Rodriguez DA, Gurung P, Savage C, Kanneganti TD, Green DR (2013). Protective roles for caspase- 8 and cFLIP in adult homeostasis. Cell Rep 5(2): 340-348.

63. Galluzzi L, Kepp O, Kroemer G (2014). MLKL regulates necrotic plasma membrane permeabilization. Cell Res 24(2): 139-140.

64. Chen X, Li W, Ren J, Huang D, He WT, Song Y, Yang C, Li W, Zheng $X$, Chen $P$, Han J (2014). Translocation of mixed lineage kinase domainlike protein to plasma membrane leads to necrotic cell death. Cell Res 24(1): 105-121.

65. Cai Z, Jitkaew S, Zhao J, Chiang HC, Choksi S, Liu J, Ward Y, Wu LG, Liu ZG (2014). Plasma membrane translocation of trimerized MLKL protein is required for TNF-induced necroptosis. Nat Cell Biol 16(1): 55-65.

66. Murphy JM, Czabotar PE, Hildebrand JM, Lucet IS, Zhang JG, Alvarez-Diaz S, Lewis R, Lalaoui N, Metcalf D, Webb Al, Young SN, Varghe- se LN, Tannahill GM, Hatchell EC, Majewski IJ, Okamoto T, Dobson RC, Hilton DJ, Babon JJ, Nicola NA, Strasser A, Silke J, Alexander WS (2013). The pseudokinase MLKL mediates necroptosis via a molecular switch mechanism. Immunity 39(3): 443-453.

67. Zhang DW, Shao J, Lin J, Zhang N, Lu BJ, Lin SC, Dong MQ, Han J (2009). RIP3, an energy metabolism regulator that switches TNFinduced cell death from apoptosis to necrosis. Science 325(5938): 332-336.

68. Wang $Z$, Jiang $H$, Chen $S$, Du F, Wang $X$ (2012). The mitochondrial phosphatase PGAM5 functions at the convergence point of multiple necrotic death pathways. Cell 148(1-2): 228-243.

69. Sun L, Wang H, Wang Z, He S, Chen S, Liao D, Wang L, Yan J, Liu W, Lei $X$, Wang $X$ (2012). Mixed lineage kinase domain-like protein mediates necrosis signaling downstream of RIP3 kinase. Cell 148(1-2): 213227.

70. Tait SW, Oberst A, Quarato G, Milasta S, Haller M, Wang R, Karvela M, Ichim G, Yatim N, Albert ML, Kidd G, Wakefield R, Frase S, Krautwald S, Linkermann A, Green DR (2013). Widespread mitochondrial depletion via mitophagy does not compromise necroptosis. Cell Rep 5(4): 878-885

71. Moriwaki K, Farias Luz N, Balaji S, De Rosa MJ, O'Donnell CL, Gough PJ, Bertin J, Welsh RM, Chan FK (2016). The Mitochondrial Phosphatase PGAM5 Is Dispensable for Necroptosis but Promotes Inflammasome Activation in Macrophages. J Immunol 196(1): 407-415.

72. Karch J, Kanisicak O, Brody MJ, Sargent MA, Michael DM, Molkentin JD (2015). Necroptosis Interfaces with MOMP and the MPTP in Mediating Cell Death. PLoS One 10(6): e0130520.

73. Baines CP, Kaiser RA, Purcell NH, Blair NS, Osinska H, Hambleton MA, Brunskill EW, Sayen MR, Gottlieb RA, Dorn GW, Robbins J, Molkentin JD (2005). Loss of cyclophilin D reveals a critical role for mitochondrial permeability transition in cell death. Nature 434(7033): 658-662.

74. Nakagawa T, Shimizu S, Watanabe T, Yamaguchi O, Otsu K, Yamagata $H$, Inohara $H$, Kubo $T$, Tsujimoto $Y$ (2005). Cyclophilin Ddependent mitochondrial permeability transition regulates some necrotic but not apoptotic cell death. Nature 434(7033): 652-658.

75. Schinzel AC, Takeuchi O, Huang Z, Fisher JK, Zhou Z, Rubens J, Hetz C, Danial NN, Moskowitz MA, Korsmeyer SJ (2005). Cyclophilin D is a component of mitochondrial permeability transition and mediates neuronal cell death after focal cerebral ischemia. Proc Natl Acad Sci U S A 102(34): 12005-12010.

76. Bonora M, Bononi A, De Marchi E, Giorgi C, Lebiedzinska M, Marchi S, Patergnani S, Rimessi A, Suski JM, Wojtala A, Wieckowski MR, Kroemer G, Galluzzi L, Pinton P (2013). Role of the c subunit of the FO ATP synthase in mitochondrial permeability transition. Cell Cycle 12(4): 674-683.

77. Yang WS, SriRamaratnam R, Welsch ME, Shimada K, Skouta R, Viswanathan VS, Cheah JH, Clemons PA, Shamji AF, Clish CB, Brown LM, Girotti AW, Cornish VW, Schreiber SL, Stockwell BR (2014). Regulation of ferroptotic cancer cell death by GPX4. Cell 156(1-2): 317-331.

78. Matsushita M, Freigang S, Schneider C, Conrad M, Bornkamm GW, Kopf M (2015). T cell lipid peroxidation induces ferroptosis and prevents immunity to infection. J Exp Med 212(4): 555-568.

79. Skouta R, Dixon SJ, Wang J, Dunn DE, Orman M, Shimada K, Rosenberg PA, Lo DC, Weinberg JM, Linkermann A, Stockwell BR (2014) Ferrostatins inhibit oxidative lipid damage and cell death in diverse disease models. J Am Chem Soc 136(12): 4551-4556.

80. Dixon SJ, Stockwell BR (2014). The role of iron and reactive oxygen species in cell death. Nat Chem Biol 10(1): 9-17. 
81. Andrabi SA, Dawson TM, Dawson VL (2008). Mitochondrial and nuclear cross talk in cell death: parthanatos. Ann N Y Acad Sci 1147:233-241

82. Cimadamore F, Curchoe CL, Alderson N, Scott F, Salvesen G, Terskikh AV (2009). Nicotinamide rescues human embryonic stem cellderived neuroectoderm from parthanatic cell death. Stem Cells 27(8): 1772-1781.

83. Wang Y, Kim NS, Haince JF, Kang HC, David KK, Andrabi SA, Poirier GG, Dawson VL, Dawson TM (2011). Poly(ADP-ribose) (PAR) binding to apoptosis-inducing factor is critical for PAR polymerase-1-dependent cell death (parthanatos). Sci Signal 4(167): ra20.

84. Menger L, Vacchelli E, Adjemian S, Martins I, Ma Y, Shen S, Yamazaki T, Sukkurwala AQ, Michaud M, Mignot G, Schlemmer F, Sulpice E, Locher C, Gidrol X, Ghiringhelli F, Modjtahedi N, Galluzzi L, Andre F, Zitvogel L, Kepp O, Kroemer G (2012). Cardiac glycosides exert anticancer effects by inducing immunogenic cell death. Sci Transl Med 4(143): 143 ra199.

85. Zitvogel L, Kepp O, Galluzzi L, Kroemer G (2012). Inflammasomes in carcinogenesis and anticancer immune responses. Nat Immunol 13(4): 343-351.

86. Bergsbaken T, Fink SL, Cookson BT (2009). Pyroptosis: host cell death and inflammation. Nat Rev Microbiol 7(2): 99-109.

87. Kepp O, Galluzzi L, Zitvogel L, Kroemer G (2010). Pyroptosis - a cell death modality of its kind? Eur J Immunol 40(3): 627-630.

88. Gurung P, Lukens JR, Kanneganti TD (2015). Mitochondria: diversity in the regulation of the NLRP3 inflammasome. Trends Mol Med 21(3): 193-201.

89. Jesenberger V, Procyk KJ, Yuan J, Reipert S, Baccarini M (2000). Salmonella-induced caspase-2 activation in macrophages: a novel mechanism in pathogen-mediated apoptosis. J Exp Med 192(7): 10351046.
90. Cervantes J, Nagata T, Uchijima M, Shibata K, Koide Y (2008). Intracytosolic Listeria monocytogenes induces cell death through caspase-1 activation in murine macrophages. Cell Microbiol 10(1): 41-52.

91. Fink SL, Cookson BT (2006). Caspase-1-dependent pore formation during pyroptosis leads to osmotic lysis of infected host macrophages. Cell Microbiol 8(11): 1812-1825.

92. Buttner S, Eisenberg T, Herker E, Carmona-Gutierrez D, Kroemer G, Madeo $F$ (2006). Why yeast cells can undergo apoptosis: death in times of peace, love, and war. J Cell Biol 175(4): 521-525.

93. Carmona-Gutierrez D, Kroemer G, Madeo F (2012). When death was young: an ancestral apoptotic network in bacteria. Mol Cell 46(5): 552-554.

94. Dwyer DJ, Camacho DM, Kohanski MA, Callura JM, Collins JJ (2012). Antibiotic-induced bacterial cell death exhibits physiological and biochemical hallmarks of apoptosis. Mol Cell 46(5): 561-572.

95. Eisenberg T, Buttner S, Kroemer G, Madeo F (2007). The mitochondrial pathway in yeast apoptosis. Apoptosis 12(5): 1011-1023.

96. Carmona-Gutierrez D, Eisenberg T, Buttner S, Meisinger C, Kroemer $G$, Madeo $F$ (2010). Apoptosis in yeast: triggers, pathways, subroutines. Cell Death Differ 17(5): 763-773.

97. Madeo F, Carmona-Gutierrez D, Ring J, Buttner S, Eisenberg T, Kroemer G (2009). Caspase-dependent and caspase-independent cell death pathways in yeast. Biochem Biophys Res Commun 382(2): 227 231.

98. Yuan J, Horvitz HR (2004). A first insight into the molecular mechanisms of apoptosis. Cell 116(2 Suppl): S53-56, 51 p following S59.

99. Steller H (2008). Regulation of apoptosis in Drosophila. Cell Death Differ 15(7): 1132-1138. 